\title{
Error Analysis of Indonesian Grammatical Interference in Students' English Composition
}

\author{
Puspita \\ Plantation Management Study Program, State Polytechnic of Agriculture, Samarinda, Indonesia \\ puspita@politanisamarinda.ac.id
}

\begin{abstract}
The first language (L1) of learners has a significant effect in learning a foreign language. The influence of L1 could become errors, that is called interference. The main purposes of the study are to identify the most dominant type of language interference and the factors contribute to language interference in students' English composition. The data were collected from 67 Second Grade Students of Plantation Management Study Program in State Polytechnic of Agriculture, Samarinda for the Academic Year 2019/2020, and taken through elicitation technique and documentation, and then analyzed the errors. The result of the study shows that the type of grammatical interference comprise morphological errors and syntactical errors were the most troublesome areas of language that students encountered when conducting composition in English. Since the main focus of the study is L1 interference, only errors related to Indonesian as L1 interference were addressed.
\end{abstract}

Keywords - L1 interference, grammatical interference, morphological errors, syntactical errors, students' composition.

\section{INTRODUCTION}

Learning a new language will involves committing errors. This is due to the fact that learners, conscious or unconscious, commonly use their first language (L1) to try to communicate in the second one, which makes learners follow the same grammatical patterns in both languages. It could be said that the L1 has an effect on the second language (L2) or foreign language. L1 interference affects L2 learning as 'language' is considered as a set of new habits while 'learning' is considered as the establishment of habits (Jie, 2008 in Yuniswati, 2017).

English in Indonesia is taught as a Foreign Language in school, so students are exposed to their native language most of the time. It is in line with Richards, et al.'s (2002) in Elkilic (2012) statement that foreign language is the language which is taught in school but it is not used in daily conversation. This situation causes interference of the mother tongue at the moment of learning the English language. This interference problem is evident when using productive skills, especially in conveying written messages. Therefore, Indonesian students use Indonesia written structures when writing English composition. It is also common for students to translate word for word from Indonesia into English. As a result, L1 has a negative influence when writing in
English (Lopez, 2011). This transfer of structures from L1 to $\mathrm{L} 2$ is a phenomenon that the present study intends to analyze.

In the teaching-learning process, one of important aspects that can contribute to an effective communication in the English language is the knowledge of the L1 interference. In addition, it is essential to achieve an effective communication through the integration of all four language skills (reading, writing, listening, and speaking) due to the fact that the main objective of teaching and learning any language is the integration of the linguistic skills that develop communicative competence with an emphasis on real life situations (Akram \& Malik, 2010) in Solano, et al, (2014)).

The L1 interference is a factor that interferes the development of the writing skill in the foreign language, which can produce a negative effect on language learning. In this regard, Bhela (1999) explains that in the event that learners do not know syntactical structures in their second language (L2), they use syntactical items of their L1 to adapt their L2 written utterances.

Throughout the study, the researcher had observed that such errors were actually perceived in writing skills, obstructing the acquisition of the foreign language. Likewise, the researcher found the evident of language transfer in the students' composition, since they were not able to produce adequate writing assignments even in their L1. These following examples of L1 interference case in L2 learning are found in some English composition assignments committed by the students:

1. Indonesia: Siswa mengumpulkan tugas kemarin.

English : The students collect their assignment yesterday.

2. Indonesia: Saya membagi-bagikan buah untuk teman-teman tadi malam.

English : I divide the fruit for friends last night.

The above case in point show intertwined interference (viewed from morphological and syntactical factor). The absence of past form of verbs with bound morpheme -ed to become 'collected' and 'divided' in relation to the past time expression might occur because of the tenseless case in Indonesian; besides the choice of word collect and divide is not appropriate since these verbs do not really collocate with the words assignment and fruit. The problem seems as the result of translating Indonesian into English for the verb 'mengumpulkan' (collect), and 'membagi' (divide). The statement should be cured to become: 


\section{The students submitted their assignment yesterday. \\ 2. I gave the fruit for friends last night.}

Such data are illustrations of the possible other grammatical interference that can be encountered in students' composition. And they lead the researcher to investigate and analyse problems dealing with students' composition related to grammatical interference from Indonesian into English. The analysis is on categorizing the patterns of the grammatical interference.

\section{LITERATURE REVIEW}

\section{A. Language Interference}

Weinrich (1968: 14), who has firstly used the term of interference stated that interference is the deviation of language norm in usage as the effect of bilingual toward another language. More specifically, he says interference is defined as a deviation to the norm of both languages which occurs in the speech of a bilingual speaker.

Dulay et al (1982: 98) argued that interference is the automatic transfer, due to habit, of the surface structure of the first language onto the surface of the target language. Interference is the deviation of target language as a result of their familiarity with more than one language. They differentiate interference into two parts, the psychological and sociolinguistic. The psychological refers to the influence of old habits when new ones are being learned, whereas sociolinguistic refers to interactions of language when two language communities are in contact. Therefore students will find it difficult in mastering the second language due to the interference, which is influenced by old habit, familiar with mother tongue and interaction of two languages in the communities (Samingan, 2016).

Abdulhayi (1985:8) referring to Valdman's point of view in 1966 theorized that interference is an obstacle as a result of speaker's habits on first language (L1) in the study of language acquisition of second language (L2). Consequently, there will be transfer of negative elements from the mother language into the target language. In other word, the speaker uses negative elements of first language in target language or second language. While Ellis (1997: 51) in Charles Owu-Ewie (2016) referred to interference as 'transfer', which he said that it was the impact that the learner's native language exerts over the acquisition of target language. He asserted that transfer is governed by learners' perceptions about what is transferable and by their stage of development in target language learning. Yusuf (1994:67) as mentioned by Vâlcea (2020) stated that the main factors of interference are the differences between the source language and the target language. The differences are not only in structure but also the variety of vocabularies. The main factor of interference is because of the difference of grammar or structure between source of language or first language and target language or second language. Lott (1983: 256) defined interference as errors in the learner's use of the second language or foreign language which can be traced back to the mother tongue or first language. In other word, language learners use the structure of first language in target language.

\section{B. Factors Contribute Interference}

Weinrich (1970: 64) explained that there are many factors that contribute interference; First, speaker bilingualism background. Bilingualism is the major factor of interference as the speaker is influenced by both of the source and the target language. Second, disloyalty to target language. Disloyalty to target language will cause negative attitude. This will lead to disobedience to target language structure and further force the bilingualist to put uncontrolled structure of his first language elements to output in practicing words utterances both oral and written. Students whose language background of TL is limited tend to put words in sentences or oral in structure and sense of first language. Third, the limited vocabularies of TL mastered by a learner. Vocabularies of certain language mostly are about words of surroundings connected to life. Thus, a learner who is willing to master another language will meet new words differ from his native words and etc. Henceforth, interference may be called as a negative transfer. It may come from students' first language or mother tongue. Two aspects that can be potential problems are pronunciation and grammar. Bahasa Indonesia and English have different rule in those two aspects. Interference may happen in transferring the Indonesian language system to English. Fourth, Needs of synonym. Synonym in language usage plays an important role as word chosen variation in order not to repeat similar word during the communication process (redundancy). Implementing synonym in a language contact will contribute to interference in the form of adoption and borrowing of new words from SL to TL. Thus, need of synonym for certain word from SL to TL is seemingly aimed to intensify meaning. Fifth, Prestige and style. Applying unfamiliar words (foreign words) during a communication practice which dominant words are languages of both speaker and receiver is something else. Those unfamiliar words usage is aimed to get a pride. Interference will appear as there are certain words even though the receiver probably cannot catch the real idea of the speech. The usual unfamiliar words usage will become a style of the user. Unfortunately, the user sometimes does not understand the real meaning whether the meaning is denotative or connotative. The common feature is that many language users put derivational affix -ization in every word. To note, affix -ization is an adopting and borrowing process from English to state nouns.

\section{Grammatical Interference}

Weinreich (1953) divides interference forms into three parts; phonological interference, lexical interference, and grammatical interference. Grammatical interference occurs when second language learners apply the grammatical pattern, they learn in their first language to the target language. Grammatical interference can be identified in two kinds. First, the morphological interference is the interference that absorbs the affixes from other language. Second, the syntactical interference is the syntactic of a language that is absorbed by other 
language. In Indonesian and English context, it is common to see the syntactical interference. For example, 'girl beautiful' is the misplaced of 'beautiful girl' since it is affected by the structure of Indonesian. Considering the definitions of grammar and interference, grammatical interference also may occur in writing caused by the negative transfer of structures from first language, in this case Indonesian, to the target language. An error analysis can be one of the methods to know the grammatical interference in students' writing. Further, the grammatical interference in writing that is known by analyzing the errors will provide the information how the L2 learners learn the language and how much the L2 learners have learned (Shahin, 2011: 210). In this study, the researcher only focuses on analyzing the grammatical errors due to the L1 interference.

\section{METHODS}

\section{A. Research Design}

The study employed a qualitative-descriptive supported by simple quantitative calculation for analyzing the information that was gathered.

In this design, the qualitative data was collected and analyzed first by using Error Analysis (Corder, 1981). With respect to the quantitative data, result of students' compositions and questionnaires, were tabulated using tables in Excel containing the questions and variables of the instruments for collecting data; the corresponding frequencies and percentages were then calculated. These tables were interpreted based on their results. This information was subsequently used to write a handout about teaching strategies for reducing and preventing further L1 interference.

The narrative compositions were analyzed by counting and classifying the interference errors into categories in order to determine which errors were produced by the students, i.e. to obtain the variables for the study. The results were represented as tables, indicating the most frequent interference errors made by students.

In this phase, the most frequent interference errors from the students' compositions were linguistically analyzed by considering their grammatical features. For the purpose of this study, the most representative sentences with errors were selected and analyzed individually.

\section{B. Participants}

The study took 67 second grade students of Plantation Management Study Program in State Polytechnic of Agriculture, Samarinda for the Academic Year 2019/2020 as the participant of the study. The researcher used simple random sampling technique.

\section{Research Instruments}

The following instruments were designed considering the specific objectives of this study:

1. A written test in which students were asked to write a narrative story. Students were advised to write the main idea, the supporting ideas and a concluding sentence. Moreover, the students were given 20 minutes to write free simple narrative story (there was a minimum word limit of 100 words and a maximum of 150 words for this).

2. A student's questionnaire consisting of fourteen questions. The questionnaire dealt with students' problems during writing and the factors cause errors. The researcher chose a questionnaire in order to obtain specific information from students, that is, the main difficulties when they are trying to write especially in narrative composition. It was intended to explore the students' problems in writing narrative text and it comprises 14 statements tailored according to their occurrence in terms of time of frequency ranging from "always" to "never". The items of the questionnaire were translated into Indonesian orally by the researcher to prevent any interference due to misunderstandings in L2.

\section{Data Collection Technique}

The data of this study was taken from the 67 writing tests of the second grade students at Politeknik Pertanian Negeri Samarinda in the Academic Year of 2019/2020.

The statistical method used for this study is based on concepts of descriptive statistics, particularly, frequency distribution and simple random sampling technique. Sugiono (200) explain that random sampling gives an equal chance to the population of being included in a sample and the probability is not affected. Based on this theory, a sample of the students was randomly selected so as to obtain the information. Then, the researcher asked the students for writing a narrative texts and applied the questionnaires.

Afterwards, the information was organized and tabulated to determine and analyze the interlingual errors variables. For this purpose, a table containing all the questions and variables of the instruments was designed in order to count the number of occurrences of the responses. Once the frequencies (number of occurrences of each response) were established, the percentages were calculated.

\section{E. Data Analysis}

Steps of error analysis specified by Corder (1981) are as follow:

1. Collection of data

Participants were administered a writing test that involved essay writing. They were required to write a free narrative essay according the topic that their lecturers had given to them.

\section{Identification of errors}

The researcher delved acquired data and categorized the errors based on the theory of Weinreich' errors categories. The researcher tried to analyze the data as objective as possible. Each essay was examined word by word and sentence by sentence. The researcher generated the coding categories based on all writing samples.

3. Classification of error.

Once the errors had been identified, the researcher analyzed the errors by underlining the error items.

4. Quantification of errors 
the researcher classified the errors into type of errors categories and subcategories by using frequent distribution table, and then calculated their percentages of errors individually. Based on Duscova (1969) and Scharchteran \& Celce Murcia (1997) in Ratnaningsih \& Azizah (2019), the formula for finding the percentages of errors as follows:

$$
\text { percent of error }=\frac{[\text { measure value }- \text { actual value }]}{\text { actual value }} \times 100 \%
$$

\section{Explanation of errors}

The last step would be explanation of errors by drawing a conclusion based on the analysis. In this step, the researcher had to make a valid conclusion in the form of a brief description of the errors.

\section{FINDINGS}

\section{A. The Most Dominant Types of Grammatical Interferences}

Table 1 shows an Error Analysis result of grammatical interference involves three most dominant types of grammatical interference obtained from morphological errors of the students' composition based on the recapitulation of interference, comprise tense, singular/plural, and articles.

Table 1. Error Analysis Result of Grammatical Interference

\begin{tabular}{|c|c|l|l|l|c|}
\hline Category & $\#$ & Sub category & Freq. & \% & Rank \\
\hline & 1 & Tense & 176 & $34 \%$ & $\mathbf{1}$ \\
& 2 & Articles & 84 & $16 \%$ & $\mathbf{3}$ \\
Morphological & 3 & Pronouns & 34 & $7 \%$ & 5 \\
Errors & 4 & Singular/plural & 87 & $17 \%$ & $\mathbf{2}$ \\
& 5 & Prepositions & 28 & $5 \%$ & 6 \\
& & Total & 409 & $79 \%$ & \\
\hline \multirow{2}{*}{ Syntactical } & 6 & Word Order & 76 & $15 \%$ & 4 \\
Errors & 7 & Agreement & 24 & $5 \%$ & 7 \\
& 8 & Negation & 11 & $2 \%$ & 8 \\
\hline Total & & Total & 111 & $21 \%$ & \\
\hline
\end{tabular}

Identification of 8 sub categories of interference indicates that the students had the greatest problem in tenses $(34 \%)$. The second and third most dominant errors were found in singular/plural nouns (17\%) and articles (16\%).

\section{$B$. The factors contribute to language interference}

\section{a. Morphological Errors}

\section{Interference in the use of Tenses}

Tenses is the most prominent feature of grammatical interference identified in the students' composition. The study has 176 tenses errors or $34 \%$ out of total morphological interference. Since the genre of the essay given to the students is narrative, it could somehow be predicted that they tend to commit errors on the application of Past Tense. Indonesian has different grammatical rules from English. Verb doesn't have to change from the present to past or future and in English verb needs to change from the present to past or future to express the tense. Especially for the past verb which is divided into regular and irregular verb is confusing enough for the students because it is not available in Indonesian. Sometimes it happened when students have learnt a rule of grammar and they apply it the rule for all other rules and this source of error called intralingual transfer. The followings are examples of Tenses errors as shown the data:

Table 2. Interference in the use of Tenses

\begin{tabular}{|c|c|}
\hline L1 Interference & Expected L2 \\
\hline $\begin{array}{l}\text { a. Cinderella live with her } \\
\text { step mother and sisters } \\
\text { b. ....the seven dwarves } \\
\text { comed home from } \\
\text { working, they finded } \\
\text { Snow White was sleeping. } \\
\text { c. Dayang Sumbi angry }\end{array}$ & $\begin{array}{l}\text { a. Cinderella lived with her step } \\
\text { mother and sisters. } \\
\text { b. ...the seven dwarves came } \\
\text { home from working, they } \\
\text { found Snow White was } \\
\text { sleeping. } \\
\text { c. Dayang Sumbi was angry. }\end{array}$ \\
\hline
\end{tabular}

The error can be seen in the use of the present verb instead of the past verb. In the past regular verb, the verbs 'live' should be 'lived'. In Indonesian, there is no such thing as a verb tense rule that requires the $-d$ or $-e d$ inflections at the end of the verb to indicate the past action. In English, however, the $-d$ or $-e d$ inflections are required.

The difference between a regular and an irregular verb is the formation of the simple past and past participle. Regular verbs are dependably consistent - the simple past ends in -ed as does the past participle. In contrast, the simple past and past participle of irregular verbs can end in a variety of ways, with absolutely no consistent pattern.

The absence of the finite verb in the sentence is other errors found in the students' compositions. An equivalent sentence in the first language is Dayang Sumbi marah. In Indonesian, this sentence is grammatically correct. In English, however, this sentence is ungrammatical, since it does not have a copulative verb.

In Indonesian, the word berada and adalah correspond to the English copula to be. However, they are frequently optional. These are dropped in a sentence that expresses a condition or state of existence (Swan and Smith, 2010). Thereby, this error is derived from the negative transfer of the mother tongue, since, in Indonesian, a complete sentence may have the absence of copulative verb.

\section{Interference in the use of Articles}

The total number of errors counted in articles is 84 . They constitute $16 \%$ of the total rate of errors.

One of the most difficult structural elements for EFL learners is the English article system (definite \& indefinite). Surprisingly, the English articles a, an, zero, and the are quite difficult to acquire not only for ESL/EFL learners but also for children learning English as a first language. Articles are believed to be a source of difficulty for learners and teachers of English as a second/foreign language, especially for those whose native languages do not have articles or do have articles or article-like morphemes which are used in ways that differ from English articles (Celce-Murcia and Larsen-Freeman, 1999). 
In this study, article use is another frequent problem in students' compositions because in Indonesian, the rule of using article is not available. The following table is example of errors in the use of articles:

Table 3. Interference in the use of Articles

\begin{tabular}{ll}
\hline \multicolumn{1}{c}{ L1 Interference } & \multicolumn{1}{c}{ Expected L2 } \\
\hline a. The smoking is bad habit. & a. Smoking is a bad habit. \\
b. Her father saw a old castle & b. Her father saw an old castle \\
when... & when... \\
$\begin{array}{ll}\text { c. His mother cursed Malin } \\
\text { Kundang became stone. }\end{array}$ & c. His mother cursed Malin \\
\end{tabular}

The student added the before the gerund 'smoking' where it is not necessary. And dropped out " $a$ " before 'bad'. This explains the student's incomplete understanding of the rule. Other mistakes were done by the students in adding $a$ instead of an before a word that begins with $a$ vowel and deleting the definite and indefinite articles that should be used in the sentence. Some students may not know when to use and when to omit them. In Indonesian, in this case, the equivalent word 'batu' (stone) can stand by itself without an article. English, however, requires the noun stone to be preceded by a determiner.

This failure to learn and understand the use of the articles explains the students' excessive use of these articles in other situations. It is quite clear that there is a problem with the students' linguistic competence in this regard. The English language system of the definite and indefinite articles might have a negative effect on the students' wrong use of these articles in the target language, and this really needs to be investigated by researchers.

Betty Scrampher (2000:125) states that the main function of articles is used as determiners that precede nouns; a, an and the. Than, in Tata Bahasa Indonesia, the same function as English articles is kata sandang. "Kata sandang sebenarnya tidak mempunyai arti, tetapi mempunyai fungsi menjadikan suatu kata itu menjadi kata benda (membedakan) dan memberikan ketentuan pada kata benda (petunjuk). Misalnya: sang, si, para, bank, dang, hang, dan sebagainya". The explanation above states that between English article and kata sandang has the same function as determiners that preceded nouns. Unfortunately, the roles in using article and kata sandang have quite different. For example: the article a if we translated into Indonesian means 'sebuah'. On the contrary, according to Tata Bahasa Indonesia, 'sebuah' does not include in kata sandang. It is so different between English and Indonesian. Therefore, most of Indonesian learners of English make errors either in spoken of written language because they may have forgotten sometimes to use or to omit articles due to the interference from their first language and this explains the occurrence of interlingual errors.

\section{Interference in the use of Pronouns}

The total number of errors counted in pronoun is 34 or $7 \%$. Pronouns are problematic because there are no exact equivalent counterparts in L1 or L2, for instance, the pronoun 'it' as a neutral pronoun is not available in L1. The misusing of object pronouns as well cause some sort of confusion since the word or morpheme may represent both an object pronoun and a possessive adjective like in (his/him, her/her, their/ them, your/you).

Pronoun errors took place when the students misused, misplaced, or omitted pronoun in their sentences. These problems can be attributed to the negative transfer of L1. Some examples of pronoun errors in the students' compositions were:

Table 4. Interference in the use of Pronouns

\begin{tabular}{ll}
\hline \multicolumn{1}{c}{ L1 Interference } & \multicolumn{2}{c}{ Expected L2 } \\
\hline \begin{tabular}{ll} 
a. The giant gave she the gourd. & a. The giant gave her the \\
b. ...the dwarfs wanted her to & gourds. \\
stay with they. & b. ...the dwarfs wanted her to \\
c. ...the giant gave a gourd her as & stay with them. \\
& c. ...the giant gave her a \\
a reward. & gourd... or ...the giant gave \\
& a gourd to her... \\
\hline
\end{tabular}
\end{tabular}

The students made some errors in the sentences above because they could not differentiate between the nominative, subjective, and objective pronoun. They also omitted pronoun that should be used in the sentence. The student omitted objective pronoun her substitutes subjective pronoun she that should be used in this sentence. The student also used incorrect objective pronoun they in the sentence. The correct one should be used in this sentence is them. The student misplace object pronoun after noun. He could placed object pronoun after noun if it preceded by preposition ' $t o$ '.

\section{Interference in the use of Singular/plural nouns}

A noun is defined as a word that is used to name any person, animal, thing, idea, state, or quality (Russell, 1993). A singular noun names one person, place, thing, or idea, while a plural noun names more than one person, place, thing, or idea.

In this study, the percentage of errors in singular/plural nouns were $17 \%$ or 87 errors counted in the texts. This type of errors is the second frequent type of grammatical errors found in the students' compositions. It is caused by interlingual transfer which in Indonesian is not available singular-plural noun. It differs from English which the singular and plural nouns are different divided into countable and uncountable plural noun, and regular and irregular plural noun.

The following table is errors in singular/plural nouns found in the students' compositions:

Table 5. Interference in the use of Singular/plural nouns

\begin{tabular}{|c|c|}
\hline L1 Interference & Expected L2 \\
\hline $\begin{array}{l}\text { a. Jaka Tarub saw seven } \\
\text { beautiful girl bathing in the } \\
\text { lake. }\end{array}$ & $\begin{array}{l}\text { a. Jaka Tarub saw seven } \\
\text { beautiful girls bathing in } \\
\text { the lake. }\end{array}$ \\
\hline $\begin{array}{l}\text { b. A thirsty crow was flying over } \\
\text { a field looking for some } \\
\text { waters. }\end{array}$ & $\begin{array}{l}\text { b. A thirsty crow was flying } \\
\text { over a field looking for } \\
\text { some water. }\end{array}$ \\
\hline $\begin{array}{l}\text { c. There was an old women lived } \\
\text { in the small village. }\end{array}$ & $\begin{array}{l}\text { c. There was an old woman } \\
\text { lived in the small village. }\end{array}$ \\
\hline
\end{tabular}

Most students still confused between regular and irregular plural nouns in the sentence. They tended to 
keep the irregular plural as singular when it is plural. They also inclined to add $-s$ to uncountable. A possible explanation for this is that students try to over-generalize the rule where $-s$ is added to all plurals. Some researchers such as Jain (1974) and Tan (1978) have attributed morphological errors like the above to overgeneralization and a simplification strategy on the learners' part (Hirpa, 2019). This means that in order to simplify things, learners often sub-categorize certain countable nouns as uncountable nouns and vice versa. Thus, the students' failure to mark plural countable nouns could probably be due to a subconscious learning strategy employed by them to lighten their memory load when managing new English data input. While some respondents are inclined to leave out the $-s$ morpheme in plural countable nouns, others have an affinity for inserting the $-s$ morpheme in singular countable nouns as well as uncountable nouns. These errors could be repercussions of constant corrections to mark their plural nouns, and thus the learners are prompted to insert the $-s$ morpheme when they should not and cannot do so.

\section{Interference in the use of Prepositions}

The amount of preposition errors counted in the students' compositions are 28 errors or $5 \%$.

Prepositions are always followed by nouns (or pronouns). They are connective words that show the relationship between the nouns following them and one of the basic sentence elements: subject, verb, object, or complement. They usually indicate relationships, such as position, place, direction, time, manner, agent, possession, and condition, between their objects and other parts of the sentence. A preposition may be composed of one, two, or three parts. For instance:

a. One part: of, on, in, at, for, from

b. Two parts: because of, according to, etc

c. Three parts: in front of, on top of, as far as, etc

In using a preposition, one should be aware that there is no certain rule for this. One has to determine which preposition should be used based on its context. The uses of English prepositions are different from the Indonesian prepositions. In using English preposition there are many things that must be noticed by the learners. They are concerning with the context. The learners sometimes get many problems caused by the differences of English and Indonesian preposition.

Some of the errors made by the students in this area are as follows:

Table 6. Interference in the use of Prepositions

\begin{tabular}{|c|c|}
\hline L1 Interference & Expected L2 \\
\hline $\begin{array}{l}\text { a. Those monkeys climbed the } \\
\text { top of the tree by wear caps } \\
\text { on their heads. }\end{array}$ & $\begin{array}{l}\text { a. Those monkeys climbed the } \\
\text { top of the tree by wearing } \\
\text { caps on their heads. }\end{array}$ \\
\hline $\begin{array}{l}\text { b. Father's Beauty went to the } \\
\text { city by on foot. (on foot) }\end{array}$ & $\begin{array}{l}\text { b. Father's Beauty went to the } \\
\text { city on foot. }\end{array}$ \\
\hline $\begin{array}{l}\text { c. There was a handsome man } \\
\text { Jaka Tarub lived at the } \\
\text { forest. }\end{array}$ & $\begin{array}{l}\text { c. There was a handsome man } \\
\text { Jaka Tarub lived in the forest. }\end{array}$ \\
\hline
\end{tabular}

In examples above, the students were not able use 'with' and ' $b y$ ' in their right places. In Indonesian structure, either 'with' or 'by' have the same meaning it is 'dengan'. However, in English, these two words are used in different situations. ' $B y$ ' is used before a noun or verb-ing when we talk about what action we take to do something; on the other hand, 'with' is used only before a noun when we talk about what we use to do something. 'dengan menggunakan' should be 'by wearing', and 'dengan berjalan kaki' should be 'on foot'.

Using the appropriate prepositions is one of the most difficult tasks of the students that's because in English there are various prepositions which have the same function.Thus, the students were not sure which prepositions to use in a certain sentence.

\section{b. Syntactical Errors}

\section{Interference in the use of Word Order}

Continuing the researcher's analysis, she observed one of the most common errors that Indonesian interference produces in English writings: word order. In the recent study, the amount of word order errors committed by the students is 76 or $15 \%$. Examples of errors that can be included in word order are shown below:

Table 7. Interference in the use of Word Order

\begin{tabular}{|c|c|}
\hline L1 Interference & Expected L2 \\
\hline $\begin{array}{l}\text { a. The king cat invited a little } \\
\text { mouse into this nest. }\end{array}$ & $\begin{array}{l}\text { a. The cat king invited a little } \\
\text { mouse into this nest. }\end{array}$ \\
\hline $\begin{array}{l}\text { b. Wife Prime Minister had } \\
\text { name Sri Tanjung. }\end{array}$ & $\begin{array}{l}\text { b. Prime Minister's wife had } \\
\text { name Sri Tanjung. }\end{array}$ \\
\hline $\begin{array}{l}\text { c. Mother Malin Kundang was } \\
\text { very happy to see Malin } \\
\text { Kundang again. }\end{array}$ & $\begin{array}{l}\text { c. Malin Kundang's mother was } \\
\text { very happy to see Malin } \\
\text { Kundang again. }\end{array}$ \\
\hline $\begin{array}{l}\text { d. They asked family Pak Pesut } \\
\text { to join with them. }\end{array}$ & $\begin{array}{l}\text { d. They asked Pak Pesut's } \\
\text { family to join with them. }\end{array}$ \\
\hline $\begin{array}{l}\text { e. All villagers there like to help } \\
\text { each others. }\end{array}$ & $\begin{array}{l}\text { e. All villagers like to help each } \\
\text { others there. }\end{array}$ \\
\hline
\end{tabular}

The phrase king cat is an error from the intended cat king. In Indonesian, the modifying word is place after the modified word. However, in English, the modifying word is put before the modified word. The incorrect placement of a group of words is caused by the influence of the native language. In English, the pattern of a noun phrase is by putting the adjective before the noun. Thus, this ungrammatical phrase can be the result of interference, since the phrase 'raja kucing' is written with the composition of Indonesian word order (Dulay, et.al., 1982).

Other mistakes are done by the students in word order is Possessive form, as shown the data mother Malin Kundang, wife Prime Minister, and family Pak pesut (example b, c, and d). These sentences described an incorrect possessive form. The student transfered the position of words in Indonesian into English, so the translation of this sentence become different. An apostrophe ('s) absolutely should be used to show possession. The accurate sentence should have been written this way; Malin Kundang's Mother, Prime Minister' wife, and Pak Pesut's family.

Moreover, the students worked with certain structures in their native language they tended to map such structures into those of the foreign language. They 
assumed that they were similar and as a consequence they produced negative transfer or language interference since structures of both languages are not the same, it is about adverbial of place. Thus, analyzing the example of the data (example e): "All villagers there like to help each others", the researcher noticed that students applied rules of Indonesian to write in English because they translated the sentence from Indonesian this way: "Seluruh penduduk desa disana saling tolong menolong." These sentences are correct in Indonesian.

Nevertheless, the students, based on this structure, assumed what they wrote in English as valid, but the researcher already knew that the pertinent rule in English for frequency adverbial of place "there" usage stated that they must be always written in the beginning or the end of the sentence, that is: "There all villagers like to help each others." Or "All villagers like to help each others there."

\section{Interference in the use of Agreement}

The next indicator the researcher analyzed from the learners' interference is agreement with 24 errors (15\%) total number of occurrences, appear to be the next most common errors committed by the students. The researcher could infer that the student literally transfered from Indonesian into English what the students wanted to express as seen in the following table:

Table 8 Interference in the use of Agreement

\begin{tabular}{ll}
\hline \multicolumn{1}{c}{ L1 Interference } & \multicolumn{1}{c}{ Expected L2 } \\
\hline $\begin{array}{l}\text { a. His wife was passed away... } \\
\text { b. Dewi Limaran was walked in } \\
\text { the garden. }\end{array}$ & $\begin{array}{l}\text { a. His wife passed away... } \\
\text { b. Dewi Limaran walked in the } \\
\text { garden. }\end{array}$ \\
$\begin{array}{ll}\text { c. They saw a garden that full of } \\
\text { bananas. }\end{array}$ & $\begin{array}{l}\text { c. They saw a garden that was } \\
\text { full of bananas. }\end{array}$ \\
$\begin{array}{ll}\text { d. Once upon a time, there was } \\
\text { two monkeys . Once upon a time, there were } \\
\text { two monkeys. }\end{array}$ \\
$\begin{array}{ll}\text { e. ... when they was tired. } & \text { e. ...when they were tired. } \\
\text { f. He knew that someone who } & \text { f. He knew that someone who } \\
\text { was stole his bananas was a } & \text { stole his bananas was a } \\
\text { human. } & \text { human. }\end{array}$ \\
\hline
\end{tabular}

The students made errors in agreement when they wrote and constructed the English sentences. they did not know when they should use 'to be' because in Indonesian structures does not need 'to $b e$ ' in constructing a sentence (example a, b, and c). The constructions do not need the 'to be' if they have verbs, and they must have 'to be' if they are in nominal case. They also got difficulties to construct the sentences using the correct agreement (example $\mathrm{d}$ and e). Those sentences must have the correct number of verbs that agree with the subject. Likewise, the students also forgot replacing the verb in the adjective clause whereas it must agree with the noun or pronoun in the main clause to which it refers (example f).

\section{Errors in the use of Negation}

The source of error that called the students' interference is Negation. Errors in Negation with 11 (2\%) total number of occurrences, appear to be the next common errors committed by the students. From the examples of the sentence seem that they unconsciously used double constituents for negation in the same sentence.

That is, they assumed they were accurate negative sentences since in Indonesian they produced utterances with similar structure. The following examples show the negation errors found in the students' composition:

Table 9.Interference in the use of Negation

\begin{tabular}{|c|c|}
\hline L1 Interference & Expected L2 \\
\hline $\begin{array}{l}\text { a. The fly was angry because the } \\
\text { bull didn't not care what the } \\
\text { fly had done. }\end{array}$ & $\begin{array}{l}\text { a. The fly was angry because } \\
\text { the bull did not care what } \\
\text { the fly had done. }\end{array}$ \\
\hline $\begin{array}{l}\text { b. This experience wasn't } \\
\text { unforgettable. }\end{array}$ & $\begin{array}{l}\text { b. This experience } \\
\text { unforgettable. }\end{array}$ \\
\hline $\begin{array}{l}\text { c. The King Mundi was not } \\
\text { unhappy... }\end{array}$ & $\begin{array}{l}\text { c. The King Mundi } \\
\text { unhappy... }\end{array}$ \\
\hline
\end{tabular}

The data above obviously shows that the students could not construct the correct sentences due to the lack of vocabulary, and they also were mapping structures and bad habit from the first language into those structures of the second language they are learning causing interlingual errors.

\section{CONCLUSSION}

Language interference is a natural phenomenon that usually appears in learning another language. Learning a new language will involves committing errors. This is due to the fact that learners, conscious or unconscious, commonly use their first language (L1) to try to communicate in the second one, which makes learners follow the same grammatical patterns in both languages.

Based on the findings of the analysis, the researcher encountered that the Second Grade Students of Plantation Management Study Program in State Polytechnic of Agriculture, Samarinda had the greatest difficulty in conducting tenses. Since the genre of the essay given to the students is narrative, it could somehow be predicted that they tend to commit errors on the application of Past Tense. Indonesian has different grammatical rules from English. Verb doesn't have to change from the present to past or future and in English verb needs to change from the present to past or future to express the tense.

The singular/plural nouns is the second frequent type of grammatical interference errors found in the students' compositions. It is caused by interlingual transfer which in Indonesian is not available singular-plural noun. It differs from English which the singular and plural nouns are different divided into countable and uncountable plural noun, and regular and irregular plural noun.

The third most frequent interference errors found in the students' compositions was articles. In this study, article use is another frequent problem in students' compositions 
because in Indonesian, the rule of using article is not available.

As one of the most difficult structural elements for EFL learners, the English article system (definite \& indefinite) are quite difficult to acquire not only for ESL/EFL learners but also for children learning English as a first language. Articles are believed to be a source of difficulty for learners and teachers of English as a second/foreign language, especially for those whose native languages do not have articles or do have articles or article-like morphemes which are used in ways that differ from English articles (Celce-Murcia \& LarsenFreeman, (1999) in Gaibani (2016))

The researcher also observed the low frequent errors in other variables. Although these low frequent errors showed that these errors were not very common, they cannot be ignored since they have a negative influence on developing writing skills in the L2.

The current study on grammatical interference has shown that there is a gap in the students' knowledge during the writing stage in English as the target language (L2), students tend to apply grammar rules from Indonesian as their first language (L1). The students' perception was that they think in their mother tongue and then translate into English. As a result, translation causes considerable interference errors. This is supported by Salih, N., \& Ridha, A. (2012)., who states that learners translate their mother tongue structures at the moment of writing texts in the target language. Consequently, the interference of the L1 is considered negative as it impedes language acquisition of the L2.

\section{REFERENCES}

Aini, N. (2018). The Grammatical Errors in the Translational Text: Indonesian-English Structure. Tell: Teaching of English Language and Literature Journal, 6(2), 55. https://doi.org/10.30651/tell.v6i2.2109

Ali Ahmed Qasem, F. (2020). Crosslinguistic Influence of the First Language: Interlingual errors in the writing of ESL Saudi learners. Macrolinguistics, $8(13)$, 105-120. https://doi.org/10.26478/ja2020.8.13.7

Azar, Betty Schrampfer (2000). Understanding and Using English Grammar 3th Edition. New York: Pierson Education.

Azar, Betty Schrampfer \& Stacy A. Hagen. (2011). Fundamentals of English Grammar 4th Edition. New York: Pierson Education.

Bhela, B. (1999). Native Language Interference in Learning a Second Language: Exploratory Case of Native Language Interference with Target Language Usage. International Education Journal, 1 (1999), 22-31. http://iej.cjb.net

Budiharto, R. A. (2019). NATIVE LANGUAGE INTERFERENCE ON TARGET LANGUAGE WRITINGS OF INDONESIAN EFL
STUDENTS: AN EXPLORATORY CASE STUDY. Indonesian EFL Journal, 5(1), 107. https://doi.org/10.25134/ieflj.v5i1.1630

Charles Owu-Ewie, C. F. L. (2016). L1 (Akan) Interference Errors in L2 (English) Writing: The Case of Three Junior High School Students in Ghana. American Journal of Language, 1, 1-18. http://www.ASRAresearch.org/ajll-vol-1-no-1$\underline{2016 /}$

Corder, Stephen Pit. (1981). Error Analysis and Interlanguage. London: Oxford University Press.

De Smet, H. (2010). Grammatical Interference (pp. 75104). https://doi.org/10.1075/ts1.90.06des

Elkilic, Gencer (2012) Mother tongue traces of Turkish university students on composition papers written in English. Procedia - Social and Behavioral $\begin{array}{llll}\text { Sciences } & 47 \quad(2012) & 656-664\end{array}$ https://doi.org/10.1016/j.sbspro.2012.06.713

Gaibani, Ahmed (2016) An Investigation into Undergraduates' Errors in the Use of the Indefinite Article at Omar Al-Mukhtar. British Journal of English Linguistics Vol.4, No.4, pp.24-33, July 2016 https://doi.org/10.7575/aiac.alls.v.6n.6p.195

Hirpa, Tadesse (2019) Analysis of Common Errors Made by Second Year English Language Department Students in Writing Academic Paragraph: The Case of Gilgel Beles CTE. Journal of Education and Practice Vol.10, No.13, 2019 https://doi.org/10.7176/jep/10-13-07

Kazazoğlu, S. (2020). The impact of L1 interference on foreign language writing: A contrastive error analysis. Journal of Language and Linguistic Studies, $\quad 16(3), \quad 1177-1188$. https://doi.org/10.17263/jlls.803621

Khumphee, S., \& Yodkamlue, B. (2017). Grammatical Errors in English Essays Written by Thai EFL Undergraduate Students. Journal of Education, 11(4), 139-154. https://www.mendeley.com/catalogue/c51261ab6875-3b49-ac11-60d9865e7837/

Linarsih, A., Irwan, D., \& Putra, M. I. R. (2020). The Interferences of Indonesian Grammatical Aspects into English: An Evaluation on Preservice English Teachers' EFL Learning. IJELTAL (Indonesian Journal of English Language Teaching and Applied Linguistics), 5(1), 69. https://doi.org/10.21093/ijeltal.v5i1.565

Mahmud, M. (2017). Interference: Its Role in the Second or Foreign Language Mastery to Indonesian Learners. Academic Journal Perspective : Education, Language, and Literature, 5(1), 52. https://doi.org/10.33603/perspective.v5i1.553 
Mubarok, Y., \& Nur'aisyah, A. H. (2020). Native Language Interference in Learning a Second Language. Buletin Al-Turas, 26(1), 173-188. https://doi.org/10.15408/bat.v26i1.13797

Muftah, M., \& Rafic-Galea, S. (2013). Error analysis of present simple tense in the interlanguage of adult arab english language learners. English Language Teaching, 6(2), 146-154. https://doi.org/10.5539/elt.v6n2p146

Olana, T., Zeleke, T., \& Jiregna, K. (2016). Mother Tongue Interference in English Language Writing at Derge Secondary School: The Case of Grade 9 Students. Science, Technology and Arts Research Journal, 4(4), 208. https://doi.org/10.4314/star.v4i4.29

Pudin, C. S. J., Storey, J. M., Len, L. Y., Swanto, S., \& Din, W. A. (2015). Exploring L1 interference in the writings of kadazandusun ESL students. Indonesian Journal of Applied Linguistics, 5(1), 52-60. https://doi.org/10.17509/ijal.v5i1.831

Ratnaningsih, S., \& Azizah, A. (2019). Error Analysis in the Descriptive Text Writing of Vocational High School Students. Dinamika Ilmu, 19(1), 175-186. https://doi.org/10.21093/di.v19i1.1364

Salih, N., \& Ridha, A. (2012). The Effect of EFL Learners' Mother Tongue on their Writings in English : An Error Analysis Study. Journal of the College of Arts. University of Basrah No, 60(60), 22-45.

https://www.mendeley.com/catalogue/ff04f0fd761a-3795-a49e-adcb34021f43/

Septiana, A. R. (2020). The Indonesian grammatical interference on EFL students' writing. Journal of Research on English and Language Learning (JREaLL), 1(1), 46. https://doi.org/10.33474/jreall.v1i1.5610

Solano, et, al (2014). Spanish Interference in EFL Writing Skills: A Case of Ecuadorian Senior High Schools. English Language Teaching; Vol. 7, No. 7; 2014 ISSN 1916-4742 E-ISSN 19164750 Published by Canadian Center of Science and Education. doi:10.5539/elt.v7n7p40 http://dx.doi.org/10.5539/elt.v7n7p40

Sugiyono. (2017). Metode Penelitian Kuantitatif, Kualitatif, dan R\&D. Bandung: Alfabeta, CV.

Sunandar, A., \& Susanti, R. (2020). Investigating Error in Written English Sentences: A case study Indonesia EFL Students. Basic and Applied Education Research Journal, 1(1), 8-16. https://doi.org/10.11594/baerj.01.01.02

Syarif, H. (2014). Factors Causing Indonesian Grammatical Interferences on English Use: A Case of Undergraduate Students ' Expository Writing in Padang, Indonesia. Language Awareness on TEFL for Multigulingual Learners,
(1999), 189-195. Retrieved from http://repository.unp.ac.id/436/

Watcharapunyawong, S., \& Usaha, S. (2013). Thai EFL students' writing errors in different text types: The interference of the first language. English Language Teaching, 6(1), 67-78. https://doi.org/10.5539/elt.v6n1p67

Yuniswati, M. (2017). The Study of L1 Interference on English Compositions Made by Eighth Graders. ELLITE: Journal of English Language, Literature, and Teaching, 2(2), 94-100. https://doi.org/10.32528/ellite.v2i2.1508

Vâlcea, C. S. (2020). First language transfer in second language acquisition as a cause for error-making in translations. Diacronia, (11). 